\title{
What Position Should Indonesia Have in Placing Its Renewable Energy Development and Energy Transition Plan?
}

\author{
Hanan Nugroho ${ }^{1}$, Dedi Rustandi ${ }^{2}$, and Nur Laila Widyastuti ${ }^{s}$
}

${ }^{1}$ Principal Planner, National Development Planning Agency, Jakarta, Indonesia

${ }^{2}$ Senior Planner, National Development Planning Agency, Jakarta, Indonesia

${ }^{3}$ Senior Planner, National Development Planning Agency, Jakarta, Indonesia

Correspondence: nugrohohn@bappenas.go.id

https://doi.org/10.47266/bwp.v4i2.100| page: 239-254

\begin{tabular}{l|l|l} 
Submitted: 16-07-2021 & Accepted: 01-09-2021 & Published: 20-09-2021
\end{tabular}

\begin{abstract}
Indonesia's energy faces a situation of giddiness in deciding a transition that requires a much larger use of renewable energy, as the country is basically a fossil fuels one but in the other side it is demanded to contribute a bigger role in efforts to mitigate global climate change. Development of Indonesia's energy-environment policies, particularly on renewable energy is highlighted. International agreements on global climate change and Indonesia's participation are described. Foundations of the successful renewable energy development are emphasized. It recommends publishing a renewable energy law, establish regulation regarding renewable energy pricing, develop a carbon pricing system, establish organizational unit regarding energyclimate change, develop renewable energy technology, improve data quality dan grid intrconnection, implement energy conservation, encourage development of REBID and REBED.
\end{abstract}

Keywords: climate change management, international agreement, energy transition, renewable energy, Indonesia 


\title{
What Position Should Indonesia $\neg$ Have in Placing Its Renewable Energy Development and Energy Transition Plan?
}

\author{
Hanan Nugroho, Dedi Rustandi, and Nur Laila Widyastuti
}

\section{Pendahuluan}

Indonesia's energy sector may face a situation of giddiness in deciding its transition towards a much larger use of renewable energy than is currently being exploited. The sector might be caught between the large hope to play larger role in mitigating climate change (through reducing emissions) contrary with the fact that its development of renewable energy is still weak.

History has recorded that Indonesia is one of the world's leading exporters of fossil fuels, a unique position compared to some other countries in Asia that are large-scale energy importers, such as Japan, South Korea, and Taiwan. With the wealth of fossil fuels (oil, natural gas, coal) in the archipelago, then it is natural that Indonesia's energy consumption is dominated by fossil fuels. However, with Indonesia's role as a sizeable energy producer and its growing for both energy consumption and green-house gases (GHG) emission, it makes sense that the country's participation in mitigating world climate change is highly desirable. Moreover, there are extensive forests in the tropical Indonesia which are expected to be maintained, because of its role as "sink" and as the lungs of the world.

The world's attention to the issue of climate change has progressed quickly, not only from being concerned about carbon dioxide $\left(\mathrm{CO}_{2}\right)$ emissions due to the burning of fossil fuels, but it has reached an agreement to maintain the earth's temperature as stated lately by the Paris Agreement (2015).

This paper highlights the development of Indonesia's energy policies, particularly on renewable energy and environmental ones relating to global climate change and energy transition. After describing international agreements on global climate change and analyzing Indonesia's renewable energy performances versus their development targets, this paper suggests fundamental steps for the country's renewable energy development to facilitate the achievement of targets for increasing the share of renewable energy as well as achieving the targets of the energy transition program.

The paper is composed as follows. It starts by describing development of international agreement on global climate change, paying emphasize on Indonesia's participation on the issue (Section 2). The next section is about development of Indonesia's energy policy, particularly that on renewable energy and related energy-environment one. Then, Section 4 follows with common debates on Indonesia's energy-environment issues. Section 5 reminds about foundation for the success of renewable energy development, followed by Section 6 showing about energy transition and the necessary works to meet the Paris Agreement. Section 7 summarizes and presents recommendations of the paper.

\section{Development of international agreement on global climate change and Indonesia's participation}

Despite the long understanding that atmospheric temperatures have an influence on the earth's surface, and those human activities, especially the burning of fossil fuels, bring with them greenhouse gas emissions, the world's attention to global climate change and actions to address them is relatively new. It was just in the late 1970 s that the WMO (World 
Meteorological Organization) began to express concern that the emission of carbon dioxide $\left(\mathrm{CO}_{2}\right)$ might lead to serious temperature increase of the earth surface atmosphere. Scientific concerns about global warming grew during the 1980s; in 1988 the WMO and UNEP (United Nations Environment Program) established the International Panel on Climate Change (IPCC). ${ }^{1}$

The 1991 United Nations Framework Convention on Climate Change (UNFCCC) was signed at the Earth Summit in Rio de Janeiro in 1992 by 166 nations and came into force in 1994. The UNFCCC firstly did not contain any specific national or international targets to reduce greenhouse gas ( $\mathrm{GHG}$ ) emissions, but it contained key points that have been foundational in subsequent international climate change debates. ${ }^{2}$

The Kyoto Protocol of the Conference of the Parties (COP-3) in 1997 was the first meeting where delegates agreed to establish emission reduction targets for several developed countries. The Protocol commits 37 industrialized countries and the European Union (Annex-Countries) to target of reducing their greenhouse gas emissions by an average of 5\% against 1990 levels, over the $2008-2012$ period. The Kyoto Protocol also introduced three mechanisms to facilitating the emission reduction targets, namely Emission Trading Scheme (ETS), Clean Development Mechanism (CDM), and Joint Implementation (JI). However, several countries, especially the United States and Australia, then refused to ratify the Kyoto Protocol and stated that developing countries must also share the responsibility to reduce carbon dioxide emissions. ${ }^{3}$

As the international debate continued, there was more and more evidence showing the effect of greenhouse gas emissions, especially carbon dioxide on global warming, which spawned a wider range of actions to deal with the growing challenges.

The COP-13 in Bali in 2007 produced the Bali Road Map consisting of some forwardlooking decisions representing the various tracks that are essential to reaching a secure climate future. The Road Map includes the Bali Action Plan, which charts the course for a new negotiating process designed to tackle climate change, along with other decisions and resolutions, aimed to complete by $2009 .^{4}$

The COP-15 in Copenhagen (2009), COP-16 in Cancún (2010) and COP-17 in Durban (2011) negotiated a legally binding treaty after the first commitment period of the Kyoto Protocol. The tiring negotiations come with important arrangements, including the Green Climate Fund, Technology Mechanism, and the Cancún Adaptation Framework and Forest Management Reference Levels.

At COP 21 in 2015 in Paris, 196 Parties reached to remarkable agreement for a legally binding international treaty on the climate change. The goal of the Paris Agreement is to limit global warming to below 2 , preferably to below 1.5 degrees Celsius compared to preindustrial levels. The agreement states that by 2020, countries should submit their NDCs (nationally determined contributions) or plans for their climate action. ${ }^{5}$

Indonesia is a quite active country participating in the negotiations on the environment, climate change and sustainable development, and sometimes even take a leading position in these matters.

Indonesia was among the 166 nations that attended the 1991 United Nations Framework Convention on Climate Change (UNFCCC) and signed it at the Earth Summit in Rio de Janeiro in 1992. In 1994, under the government of President Suharto, Indonesia

\footnotetext{
${ }^{1}$ A History of Climate Activities, https://public.wmo.int/en/bulletin/history-climate-activities

2 lbid.

${ }^{3}$ What is the Kyoto Protocol; The Kyoto mechanisms: https://unfccc.int/kyoto_protocol

${ }^{4}$ Bali Road Map Intro, https://unfccc.int/process/conferences/the-big-picture/milestones/bali-road-map

${ }^{5}$ The Paris Agreement: What is the Paris Agreement? https://unfccc.int/process-and-meetings/the-paris-agreement/the-paris-

agreement
} 
issued Law number 6 of 1994 concerning the ratification of the United Framework Conventions on Climate Change.

After going through long stages since 1997, in June 2004, Indonesia under President Megawati Soekarnoputri officially ratified the Kyoto Protocol with Law Number 17 of 2004 concerning Ratification of the Kyoto Protocol to the United Nations Framework Convention on Climate Change. In the Protocol, Indonesia was classified as a "non-Annex" country that has no obligation to reduce carbon dioxide emissions to be implemented during the years 2008-2012. However, Indonesia might take advantage of the facilities provided by the Kyoto Protocol, for example to carry out activities supported by the "Clean Development Mechanism" with "Annex Countries" partners. In 2005, Indonesia established a Designated National Authority for Clean Development Mechanism under the Kyoto Protocol.

The Indonesia's first elected President under democracy era, Susilo Bambang Yudhoyono had ordered to put environmental issues into the National Medium Term Development Plan 2004-2009 although at the start of the Medium-Term Plan, Indonesia had not yet recovered from various natural and social disasters. ${ }^{6}$ The President was then among the world leader who supports the formation of strategic policies to tackle climate change problems and influences them to the world. Under his presidency, in 2007 Indonesia successfully host COP-15 in Bali that produce the Bali Road Map and Bali Action Plan. The Bali COP-15 was attended by around 10 thousand delegates from 186 countries.

At the G20 summit in Pittsburgh in 2009 President Yudhoyono pledged Indonesia would voluntarily reduce the country's greenhouse gas emissions by 26 percent from business-as-usual levels by 2020, which can be increased to 41 percent when added with foreign aid. ${ }^{7}$ Although Indonesia was not obliged to reduce its GHG emissions under the prevailing international agreements, the President did have an interest in playing an active role in global climate change discussion. Indonesia was the first among developing countries that officially committed to voluntarily reduce the GHG emissions.

Domestically, the President's pledge in Pittsburgh became the base for the stipulation of the National Action Plan for Greenhouse Gas Emission Reduction (Presidential Regulation Number 61 of 2011), which was later derived into several Governor Regulation on Regional Action Plans regarding the same matter. The Presidential Regulation 61 of 2011 had been subsequently followed by Presidential Regulation Number 71 of 2011 concerning the Implementation of a National Greenhouse Gas Inventory. It is stated in the Regulation that the emission reduction target of 26 percent would be achieved through actions such as the following: (i) sustainable peatland management, (ii) reduction of deforestation and land degradation rates, (iii) development of carbon sequestration, (iv) promote energy conservation, (v) development of alternative and renewable energy sources, (vi) reduction of solid and liquid waste, and (vii) shifting to a low-emission mode of transportation. $^{8}$

Several institutions/offices were also formed to translate the President's pledge into implementation to the project level. Among these offices were the National Council on Climate Change (established in 2008), the Indonesian Climate Change Trust Fund (2009), and the Secretariat for the National Action Plan for Greenhouse Gas Reduction (2011). The National Development Planning Agency play as a motor in the formation and operation of those offices. In 2012, Indonesia launched its National Action Plan on Climate Change Adaptation (RAN-API) targeting food security, energy independency, health, settlement, infrastructure, urban area, coastal and small islands on the plan (Murniningtyas, 2013). In

\footnotetext{
${ }^{6}$ Government of Indonesia, The National Medium Term Development Plan 2004-2009.

7 https://redd-monitor.org/wp-content/uploads/2013/10/2009-09-25-Intervention-by-President-SBY-on-ClimateChange-at-the-G-20-Leaders-Summit.pdf

${ }^{8}$ President of Republic of Indonesia, 2011, Presidential Regulation Number 61 of 2011, set on October 5th, 2011.
} 
addition, after being formed several times as a Task Force, in 2013 the Presidential Decree 5 of 2013 was issued concerning amendments to Decree 25 of 2011 concerning the Task Force for the Institutional Preparation of Reducing Emission from Deforestation and Forest Degradation $(\mathrm{REDD}+)$, and in the same year the REDD+ Management Agency was formed.

The Joko Widodo presidency incorporated commitment towards climate change by putting in the National Medium Term Development Plan 2015-2019 a statement, "to enhance the quality of environment, disaster mitigation, and climate change." Under the President Joko Widodo, Indonesia ratified the Paris Agreement in 2016 by promulgating Law Number 16 of 2016 concerning Ratification of the Paris Agreement to The United Nations Framework Convention on Climate Change.

Following the Law 16 of 2016 regarding the ratification of the Paris Agreement, Indonesia has submitted its Nationally Determined Contribution to the United Nations Framework Convention on Climate Change (UNFCCC), and has even submitted the update.

In the submitted NDC, it was stated that Indonesia would reduce GHG emissions by 29 percent from business as usual (BAU) in 2030 using its own efforts and up to 41 percent if supported by international assistances. Indonesia's NDC states that emission reduction in Indonesia will focus on five sectors that contribute to efforts to reduce GHG emissions from 2030 BAU, namely the energy, industry, forestry, agriculture, and waste sectors. Energy sector is given emphasis as demand for energy had been forecasted would soon increase from the early 2020 es.

However, bureaucratic support and regulations related to the Paris Agreement are not similar as those during the era of President Yudhoyono, where number of offices to oversee the implementation of the National Action Plan for Greenhouse Gas Emission Reduction projects were formed. The President dissolved the Ministry of Environment, the National Council on Climate Change, the REDD + Management Agency, and merged them with the Ministry of Forestry under a new name Ministry of Environment \& Forestry. Their merger, then through the Minister of Environment and Forestry Regulation 18 of 2015, gave birth to the Directorate General of Climate Change in the ministry. ${ }^{9}$

Since the beginning of his administration, President Joko Widodo focused heavily on infrastructure development, including launching a "35,000 MW" power plant (close to the national installed capacity at that time) which relies on coal.

\section{The development of Indonesia's energy policy, with empashis on renewable energy and energy transition}

Since the beginning of the development of modern Indonesia with the initiation of the Five Years Development Plan (REPELITA) in the early 1970s to the early 2000es Indonesia's energy policy had undergone only a few fundamental changes. Since its formation in the early 1980s, the Indonesian Energy Coordinating Board (BAKOREN)- a non-structural ministrial level coordination forum led by Minister of Energy \& Mineral Resources - had issued several "General Policies for Energy Sector" (KUBE), including those related to the energy transition. The main theme of KUBE was reducing dependence on oil which needs to be pursued through the development of non-oil fuels. The still large oil

\footnotetext{
${ }^{9}$ Can be found at http://ditjenppi.menlhk.go.id/
} 
production and several price hikes in REPELITA's early periods had made Indonesia very dependent on oil as a source of energy and state revenue.10

Oil crisis that preceded in 1979 has made countries including Indonesia aware to not depend on a single type of energy. Since 1980s, Indonesia has begun to develop non-oil fuels for domestic use. Coal power plant construction was initiated including awarding $\mathrm{PKP} 2 \mathrm{~B}$ (Coal Contract of Work) Generation I in 1981 simultaneously with the preparation of coal power plants construction. Similarly, geothermal utilization for electricity was accelerated through Pertamina exploration and exploitation right (President Decree no. 22/1981). Shortly after that, the first geothermal Kamojang started to operate. In the same period, some projects of large hydropower are inisiated and planned (Cirata and Saguling).

In the early days of his presidency, in the mid of a very high increase in oil prices, President Yudhoyono issued Presidential Regulation No. 5 of 2006 concerning National Energy Policy. The President then also issued President Instruction number 1 of 2006 concerning provision and utilization of biofuels as another fuel. The latter marked the great concern of the President regarding the development of renewable energy from biofuels originating from Indonesia. A year later, the program of kerosene substitution to LPG was launched in order to reduce state budget burden for fuel subsidy.

The Law number 30 on Energy was promulgated in 2007, encouraged by the long spirit of the 1998 Reform Movement. Previously, Law Number 22 of 2001 concerning Oil and Gas, Law Number 20 of 2002 concerning Electricity, and Law Number 27 of 2003 concerning Geothermal had been promulgated. Before the Law on Oil and Gas, regarding Electricity, etc. was enacted, Indonesia had issued a Law on Nuclear Energy (Law Number 10 of 1997). Those laws form the basis of Indonesia's energy policy to date.

Energy Law number 30 of 2007, established during the presidency of Susilo Bambang Yudhoyono (the former Indonesia's Minister of Energy \& Mines) mandates the establishment of a National Energy Council, which is tasked with, among other things, to formulate National Energy Policy.

In 2008, the President issued Presidential Regulation 26 of 2008 concerning the establishment of the National Energy Council, and in the same year, Presidential Regulation 46 of 2008 concerning the establishment of the National Council on Climate Change.

The Directorate General of New \& Renewable Energy and was established in August 2010 under the President Regulation 24 of 2010. It came from several units of organization mainly from the Ministry of Energy \& Mines.

The current National Energy Policy was issued in 2014 in the form of Government Regulation Number 79 of 2014 concerning National Energy Policy. In this Government Regulation it was projected that energy demand in Indonesia will increase to 400 million tons of oil equivalent (MTOE) in 2025 and to 1,000 MTOE in 2050, while the required power generation capacity will increase to $115 \mathrm{GW}$ in 2025 and to $430 \mathrm{GW}$ by 2050 . The share of various types of energy in the national energy mix is directed to be renewable energy at least 23 percent, the share of oil is less than 25 percent, the share of coal is a maximum of 30 percent, and the share of natural gas is a maximum of 22 percent. For 2050 it is directed

${ }^{10}$ Nugroho, 2018b. Steep Road: Energy transition and the role of development planning in Indonesia. 
that the share of renewable energy is at least 31 percent, the share of oil is less than 20 percent, the share of coal is a maximum of 25 percent, and the share of natural gas is a maximum of 24 percent. The target is quite low compared to that of Japan, Western European countries or even several countries in Southeast Asia.

To make operational, the law 79 of 2014 has been translated into Presidential Regulation No. 22 of 2017 concerning the General Plan of National Energy (RUEN). The RUEN has even been broken down into currently 20 Regional Regulations (PERDA) concerning Regional Energy General Plans (RUED) at the provincial level. (National Energy Council, 2021).

Such previous energy transition is a prove that Indonesia will and has to adapt responding external and internal necessity in future. Historically, several occation of energy transition are related to the measure to relieve the dependency on oil to other type of energy as well as to ease budget burden for subsidy and as a support for current account balance. The current energy transition is more challenging as it is not only about shifting from fossil fuel energy to renewable energy, but also about how to achieve it in the most affordable way as economic growth leverage.

\section{Foundation for the success of renewable energy development}

There are many and varies renewable energy potentials in Indonesia, ranging from hydro, geothermal, various bioenergy, solar, wind, and ocean energy, which the reserves are spread differently in the vast Indonesian archipelago. However, the utilization of these renewable energy sources so far is still low compared to their potential, or only around 2.4 percent.

Figure 1 shows the potential for electricity generation from the various types of Indonesia's renewable energy, the development of the power generation capacity for each type of renewable energy, the percentage of the power generation capacity that has been built compared to the potential reserves, and the share of renewable energy in Indonesia's energy mix.

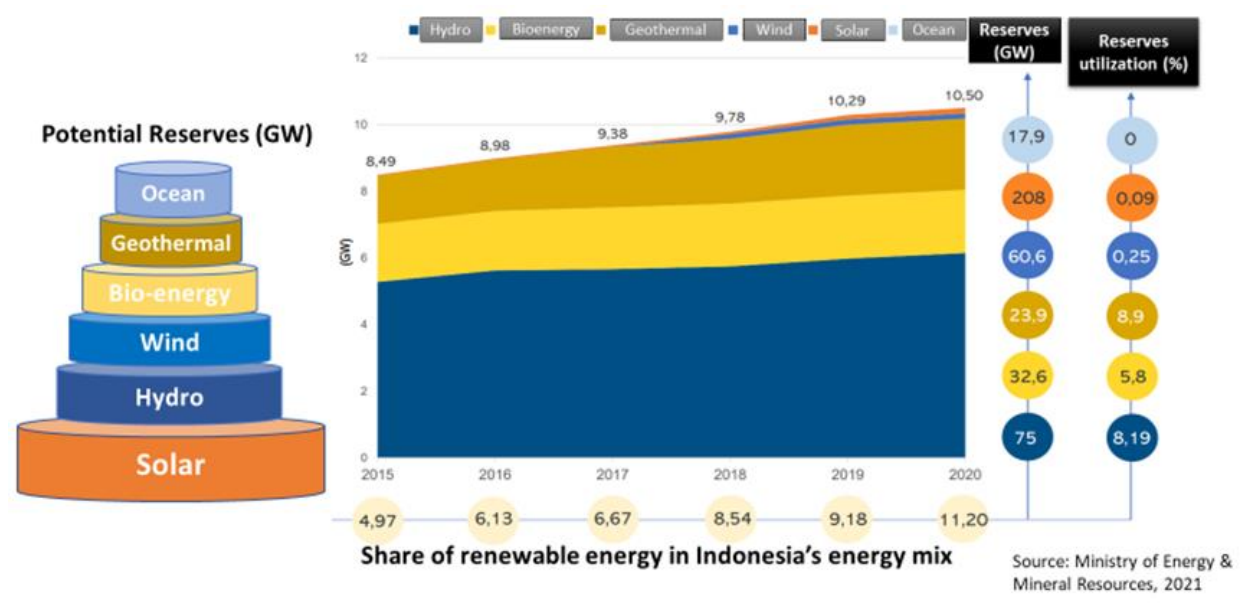

Figure 1. Indonesia's renewable energy potential for electricity, the capacity has been built, and the share of renewable energy in national energy mix. 
The development of renewable energy share in Indonesia's energy mix is quite slow. Figure 2 shows the developments in the share of renewable energy between those projected and those that have occurred over the last few years. The share of renewable energy has always been lower than the targets in the official development planning documents, even though that the targets for renewable energy development based on the National Energy Policy (GR 79 of 2014) are generally lower than the figures presented to meet the world's commitments on climate change, such as to meet the Paris Agreement targets.

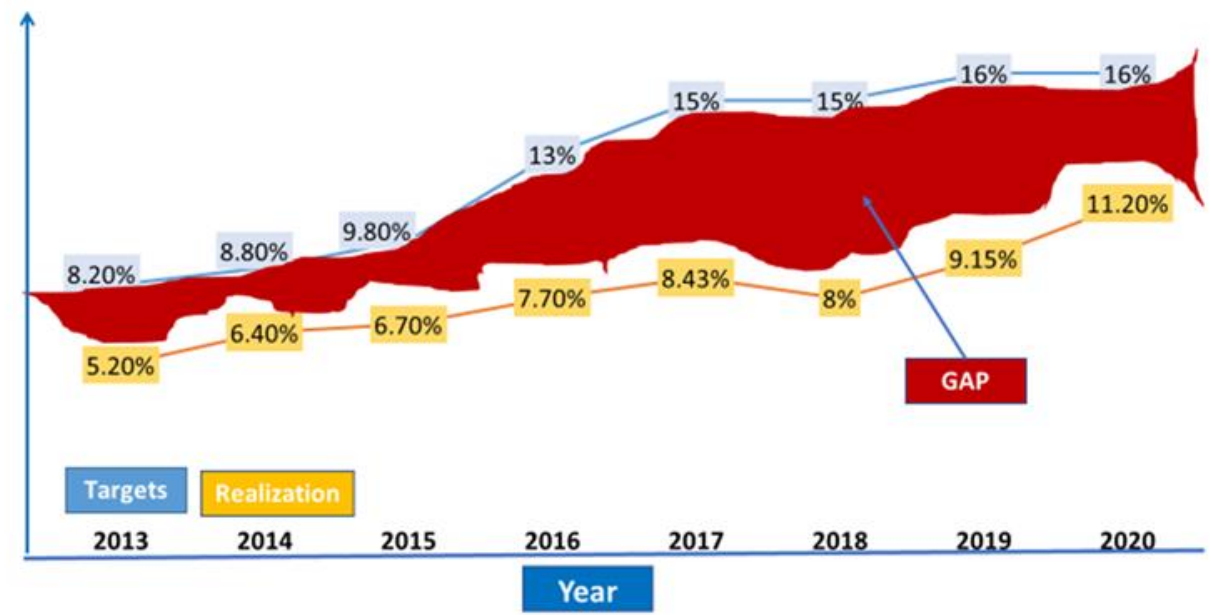

Figure 2. Development of share of renewable energy in Indonesia's primary energy mix

Source: Drawn from data by Ministry of Energy \& Mineral Resources, and National Medium Terms Development Planning 2020-2024

Based on the literature ${ }^{11}$ regarding the experiences of many countries in developing renewable energy, it can be summarized the factors that lead to successful development of energy development, including the following:

- There are laws and regulations regarding the development of renewable energy and are in favor of developing these types of energy. ${ }^{12}$

- There is an economic and investment environment that encourages the development of renewable energy. This could take the form of appropriate energy pricing policies, including carbon pricing, carbon taxes, and financing that facilitate renewable energy development. ${ }^{13}$

- Availability of innovations and renewable energy technology products that make it easier to use, cheaper, with investment and maintenance costs that compete with other energy products (derived from fossil fuels).

\footnotetext{
${ }^{11}$ For example, from Martin (2009) on Renewable Portfolio Standards; Mendonca (2007) on Feed-in tariff; Sovacool, 2012 on Renewable Energy Policy.

${ }^{12}$ An example that is often cited is Germany which has the Feed-in Act (1991) and then the Renewable Energy

Sources Act (2014) which is proven to have driven the massive growth of renewable energy in the country.

${ }^{13}$ Ibid.
} 
- Increasing public awareness, both business and general publics, about the benefits of using renewable energy in their lives, including their understanding of the issues of climate change and global warming.

- There are (number of) institutions in charge of developing renewable energy. For example, IREDA in India or SEDA in Malaysia. ${ }^{14}$

Indonesia does not yet have a modern renewable energy law such as that of Germany, even so far there is no specific law on renewable energy in Indonesia. This is different from neighboring countries such as Malaysia, which has the Malaysian Renewable Energy Act 2011, and the Philippines which has Republic Act No. 9513 on promoting the development, utilization, and commercialization of renewable energy resources. The absence of a law on renewable energy in Indonesia contrasts with the existence of laws on oil and gas (Law 22 of 2001), as well as regarding minerals and coal (Law 4 of 2009). This condition creates unbalanced playing fields, putting renewable energy in a losing position. This is exacerbated by the support of giant state-owned enterprises in the fields of oil, natural gas, coal, but almost none of them are dedicated to developing renewable energy.

The Indonesian government has applied the "feed-in tariff" concept to attract investment in renewable energy development, but has not consistently applied it, for some time resulting in the reluctance of private companies to invest. The Indonesian electricity industry is still practicing a pricing method that bias to the state-owned utility's preference, leaving only a handful of private companies willing to invest in electricity generation fueled by renewable energy, such as wind and solar power. As a result, the installed capacity of solar and wind power plants in Indonesia is lower than those installed in Malaysia, the Philippines, Thailand, and Vietnam. (IRENA, 2021).

Until now, Indonesia is classified as a country that provides energy subsidies (fossil fuels and electricity) to various groups of people, both in remote and urban areas. The amount energy subsidies are considerable, ranging from the total amount of Rp. 1.214 trillion (from 2011-2014) but decreased to Rp. 685 trillion (2015-2020). (MEMR, 2021; Nugroho, 2021). Carbon tax as well as carbon pricing is something that has not been implemented in Indonesia, although in several developed countries this has been practiced since the last 2-3 decades ago. It is not only a matter of pricing the types of renewable energy, but the concept of carbon pricing is something that Indonesia must prepare for because it will relate to the development of renewable energy in Indonesia in the coming years. Carbon pricing will place renewable energy in a very competitive position to fossil fuels.

As for renewable energy financing, in addition to the central and local government budgets that provide it (although in a limited amount), there are several international sources of financing that can be used to finance the development of renewable energy projects. However, Indonesia still makes little use of these funds. It is hampered by the ability of most of its institutions, especially in regions, which are still weak in accessing these sources of financing.

Advances in renewable energy technology have resulted in, among other things, reduced investment costs for solar and wind power plants. Although Indonesia does not contribute to the efforts to develop this technology, it can use it for the development of renewable energy widely in the country. However, this should be backed with renewable energy potential data improvement and extension of grid interconnection. Some renewable

\footnotetext{
${ }^{14}$ India Renewable Energy Development Agency (https://www.ireda.in/), Sustainable Energy Development Authority of Malaysia (http://www.seda.gov.my/).
} 
energy definitely could not be developed further due to either the potential status is still speculative or the potential has no or limited access to demand center.

The Indonesian population's understanding of the benefits of renewable energy is quite positive, but they still have limitations, especially financially, to be able to install renewable energy equipment, for example, rooftop solar panels in their homes. The understanding that renewable energy will be developed in the future needs to be cultivated among businesses and other stakeholders to anticipate and make the necessary preparations, including developing human resources. The governments need to carry out programs to develop skills related to renewable energy development.

\section{Debate on Indonesia's energy-environment issues, energy transition, and route to Paris}

All agreements on global climate change culminate in recommendations for developing renewable energy, even with an ever-increasing target. This applies to both developed and developing countries.

In addition to various concepts of energy transition towards greater use of renewable energy, "net zero emission" or "carbon neutrality" is also being promoted to avoid global warming. According to this concept, the emissions emitted by the earth must be in balance with what the earth can absorb. As for other sector such as forestry, the energy sector is asked to take responsibility for achieving this condition by reducing the burning of fossil fuels and replacing them with the use of renewable energy.

Many critics have been made, especially by the so-called environmentalist, against the development of renewable energy in Indonesia, which is said to be too little and too slow to achieve targets in the framework of world climate change agreements. Some critics even say that Indonesia should no longer build coal-fired power plants, because coal is a dirty energy having the largest carbon dioxide emissions compared to other energy sources.

Critics are often put forward by forgetting that Indonesia has quite large reserves of fossil fuels, is a country that is still maintain a status of a net exporter of energy, and that the country has developed a quite massive infrastructure to facilitate the use of fossil fuels, which is not easy to just get rid of. However, the data show that Indonesia has increased the volume of renewable energy consumption, both as fuel and for electricity generation, although for electricity generation in particular, the addition is much less than the average G-20 country. ${ }^{15}$

Jumping from heavy dependence on fossil fuels to using renewable energy is something difficult to put into practice, although energy consumption in Indonesia is increasing rapidly. Installing wind power plants in remote places is a challenging task, it is still difficult for the transportation sector to convert its petroleum-based fuel to biofuels even the raw materials are available abundantly in Indonesia, and so on. These are among the reasons for some energy analysts to defend the conditions that still prevail today, where the share of renewable energy is still small. However, as it will become clear in the next part, there are barriers to deploy renewable energy applications in Indonesia yet.

Indonesia is a country where its energy security is still weak, some people's access to energy is still poor, and the country's per capita energy consumption is still low compared to developed countries and even its neighbors in Southeast Asia. Providing public access -

\footnotetext{
${ }^{15}$ Explore “Our World in Data”, https://ourworldindata.org/
} 
especially those in remote areas, small islands, and areas close to borders with other countries - needs to be prioritized using less expensive energy and methods rather than directly installing renewable energy equipment whose operation and maintenance are expensive. It should also be borne in mind that the consumption of fossil fuels in Indonesia, which has a relatively large population, is still small compared to many developed industrial countries such as Japan, South Korea, or some Western European countries. Indonesia might solve its energy-economy-environment trilemma with an end that coal will still be needed in the future to supply energy (especially electricity) and to grow the population's economy, while maintain a little tolerance for environmental degradation.

Coal, which the availability is quite abundant in Indonesia, is a cheap energy source that can be used to increase people's access to energy particularly electricity, to increase their energy consumption as well as their economic activities and productivity. Renewable energy is still perceived as expensive, not easy to develop on a large scale or as a base load bearer (except large scale hydro or geothermal), will increase the cost of energy utilization and increase the burden of energy subsidies that must be borne by the state.

Figure 3 shows the share of coal and other energy sources in power generation, for Indonesia and the world to make a comparison. Coal's share is very dominant in Indonesia's power mix, much higher than the world's average.

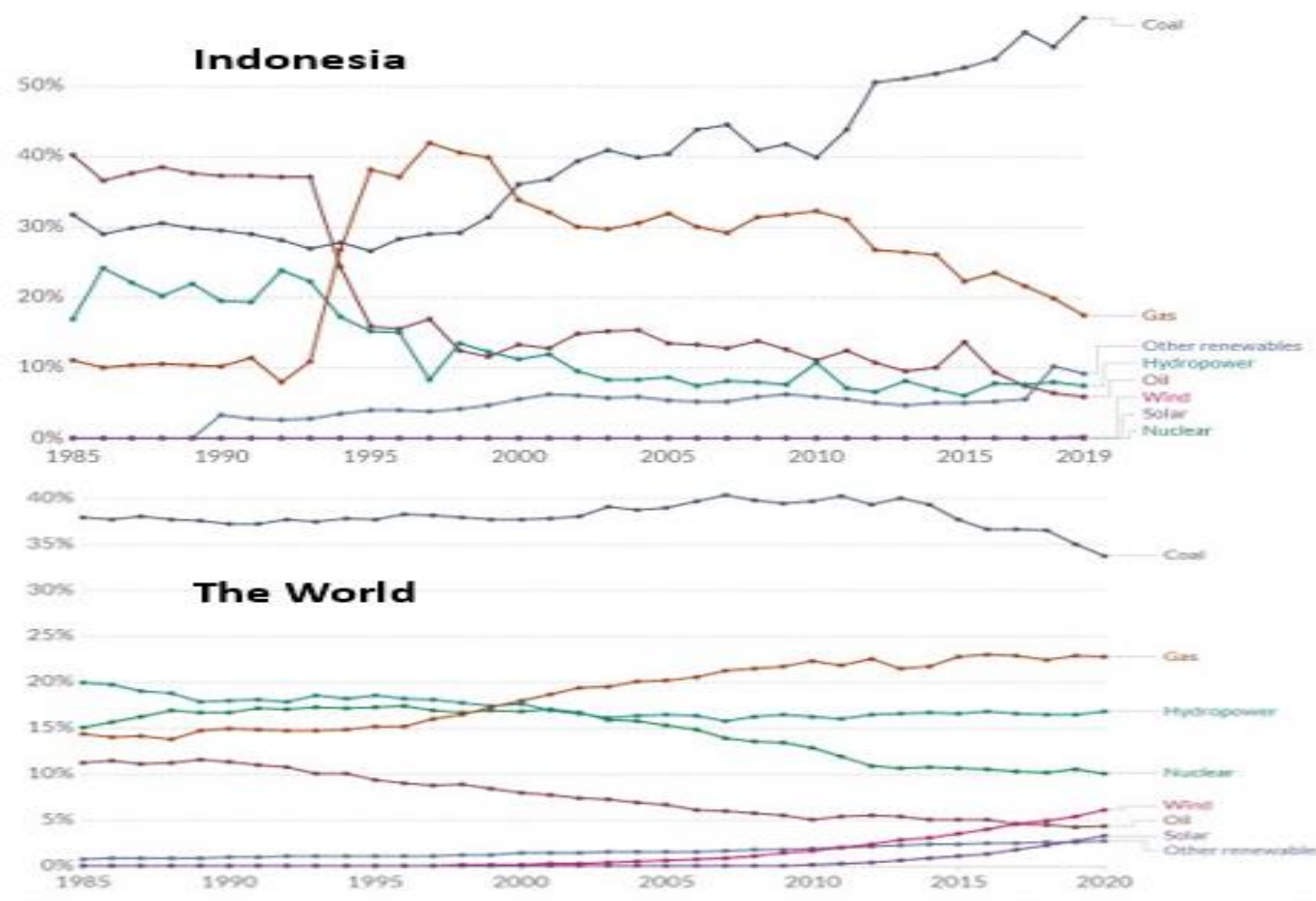

Figure 3. Share of electricity generation capacity by sources of primary energy.

Source: https://ourworldindata.org/ 
Critics of the low share of renewable energy in Indonesia's energy mix often go without questioning the root of the problem itself: why is the share of renewable energy still low? Pressure or hope is given to renewable energy to develop as soon as possible to meet the demands of global climate change, but it does not explore deeper how renewable energy can grow in the current Indonesia's energy policy environment. The fact that Indonesia has much difference with other countries in terms of geographical form should also be taken into acount. As an archipelagic country, Indonesia requires much more effort to connect renewable energy resources to demand center with interconnected grid. In fact, existing grid in almost every islands (except Java) is still disconnected and underdeveloped. On the other hand, Indonesia is the most advanced country in developing biofuel as liquid-based renewable energy which has more advantage in transportability.

GR 79 of 2014 on National Energy Policy was ratified as a Government Regulation in lieu of the Law before the Paris Agreement was announced and then ratified by the government of the Republic of Indonesia in 2016.

History recorded that Indonesia was the only OPEC member from Asia, was the world's largest of LNG (liquefied natural gas) exporting country, and even now is still listed as one of the largest coal exporters in the world. As a country having the capability to export various types of fossil fuels, it is very natural that Indonesia also consumes fossil fuels, namely oil, natural gas, and coal domestically.

The energy transition in the context that already prevails in Indonesia has been a transition from heavy dependence on oil to increasing use of natural gas (started in the 1980 s) plus the use of coal which began to increase in the early 2000 s. $^{16}$ Indonesia is quite late in developing renewable energy, except for hydropower, bioenergy, and geothermal.

In a more modern and prevailing context, the energy transition is linked to the emission of greenhouse gases produced and efforts to reduce them. Indonesia's emissions have increased by $140 \%$ between 1990 and 2017 (excl. land use), with the highest increase being the energy sector. In 2017, Indonesia's per capita GHG emissions were lower (about half) than the average emissions of OECD countries or almost the same as non-OECD countries. However, in the 2012-2017 period, Indonesia's GHG emissions increased by 7 percent, while OECD countries experienced a decrease of 5 percent. The addition of coal power plants is responsible for the increase in these emissions and into the future. ${ }^{17}$ Under current policies, emissions are projected to continue increasing to 2030.

Together with several G-20 countries, Indonesia's NDC is deemed not large enough to be able to contribute to preventing an increase in the earth's surface temperature by 2 degrees Celsius, let alone preventing an increase of 1.5 degrees Celsius. Indonesia's 2030 NDC would only limit emissions of GHG to $1,817 \mathrm{MtCO} 2 \mathrm{e}$, while the country did not increase its emissions reduction target in its updated NDC. To be compatible with the global $1.5^{\circ} \mathrm{C}$ IPCC scenarios, Indonesia needs to reduce its emissions to below $662 \mathrm{MtCO} 2 \mathrm{e}$ by 2030 and to below 51 MtCO2e by 2050. (Climate Transparency, 2021).

Indonesia has ratified The Paris Agreement, and has submitted its NDC, but this does not mean that it could instruct that plans and targets for renewable energy development follow what is stated in the NDC. Moreover, the NDCs that were compiled were not sufficiently clear or detailed for a plan to be implemented. In addition to the many weaknesses in regulations, economic incentives, technology, and institutions as stated above, another legal instrument is needed to be able to order the setting of new targets for

\footnotetext{
${ }^{16}$ Hanan Nugroho, 2018. Steep road: Energy transition and the role of development planning in Indonesia. Prisma Journal of Social Economy Thoughts, 37 (1), 3-19.

${ }_{17}$ The Climate Transparency Report 2020.
} 
renewable energy development to match the targets of emission reduction targets in accordance with the Paris Agreement. This can be done for example by changing GR 79 of 2014 regarding the National Energy Policy. However, this will take some time, while some of the things that must be prepared to support the achievement of new targets may also not be fulfilled.

Fundamentally, we need to understand that economic growth, demand for energy and emissions released by Indonesia in the last few decades have always increased for all the three variables. This is a trend that should not be sustained. However, even in GR 79 of 2014, the demand for energy is projected to continue to increase.

To get closer to achieving the Paris Agreement targets, Indonesia needs to develop an economic-energy-environment model like Germany's, where a growing economy is accompanied by lower energy use and emissions. Of course, this is possible because of the widespread application of energy conservation and the use of renewable energy in Germany's energy consumption, something that Indonesia has to fight to make it happen.

Figure 4 provides an illustration of the economic-energy-environmental developments for Indonesia and Germany over the last 3 decades.

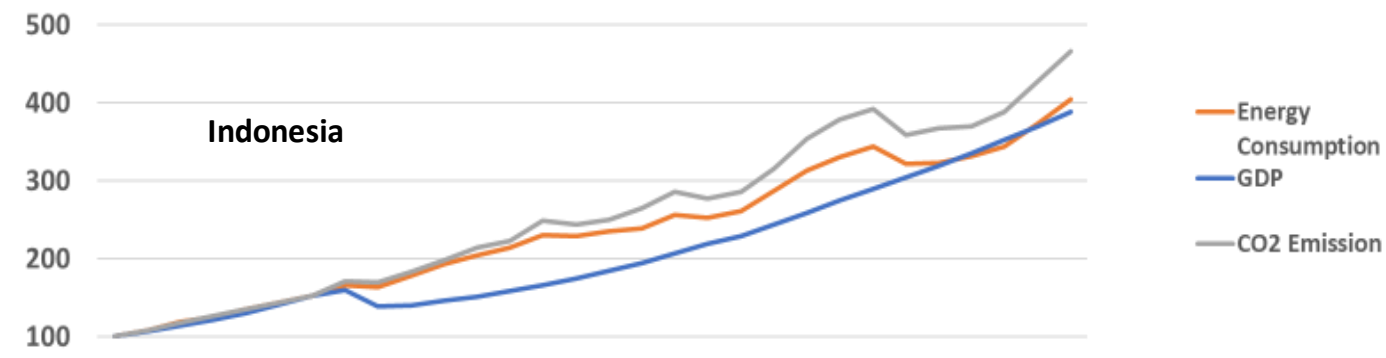

199019921994199619982000200220042006200820102012201420162018

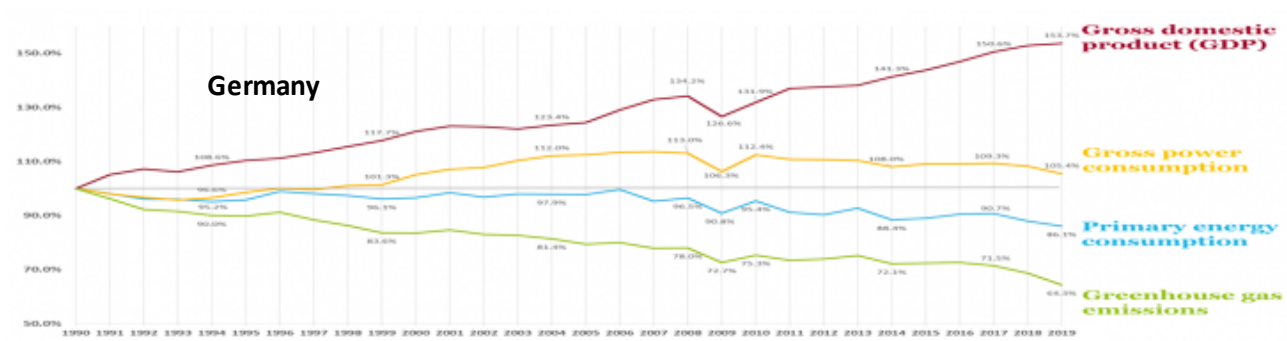

Figure 4. The growth of economy, energy consumption, and GHG emissions $(1990=100)$ Sources: Authors, and Clean Energy Wire

Therefore, while waiting for the issuance of new laws and regulations linking the Paris Agreement with Indonesia's renewable energy development goals, it is necessary to do the following basic things.

- Ensure that the Law on New \& Renewable Energy will soon be promulgated. The law should ease the process to get licenses and permits for renewable energy 
projects, mandates to fulfill obligations of meeting Renewable Portfolio Standard (RPS) for utilities, among others.

- Establish regulations (if it is necessary in the energy law to be established) regarding renewable energy pricing, with the spirit of making it easy for each type of renewable energy to develop. The pricing system can take the Feed-in or "auction" model depending on the development stage and scale of each renewable energy.

- Develop and implement a carbon pricing system, which may be preceded by removing subsidies for fossil fuels, implementing a carbon tax, developing a carbon trading system, and so on. The application of a carbon pricing system will increase the competitiveness of renewable energy against fossil fuels.

- Establish organizational units regarding climate change in government offices, especially those closely related to climate change issues such as the Ministry of Energy, Industry, Transportation, Public Works, Agriculture, etc. It also teaches the issue of climate change and its challenges in education in schools/universities and prepares the vocational workforce to be able to do jobs related to climate change in the future.

- Developing technology and industries related to increasing the contribution of renewable energy, especially those sourced from within the country, such as palm oil and other bioenergy, various kinds of biogas, small-scale geothermal, electric batteries, and nuclear power plants. ${ }^{18}$

- Improve data quality dan grid interconnection to enable more renewable energy potential for further development.

- Implementing energy conservation, apart from its potential to reduce the rate of additional energy consumption, also because it will indirectly increase the share of renewable energy in the energy mix.

- Encourage the development of Renewable Energy Based Industrial Development (REBID) and Renewable Energy Based Economic Development (REBED).

\section{Summary and Recommendation}

Indonesia has a considerable wealth of energy resources, both fossil and renewable energy. Indonesia's economy and energy supply system has relied on fossil fuels in more than half a century. Apart from its role as a producer and exporter of fossil fuels, Indonesia is active in activities regarding climate change and its international negotiations, including that of the Rio Earth Summit, the Kyoto Protocol, the Paris Agreement, and so on.

The current Indonesia's energy policy is stipulated by Government Regulation No. 79 of 2014 on National Energy Policy. Indonesia has developed regulations related to renewable energy development; however, the regulation lacks behind that of oil, natural, and coal. In fact, coal dominates Indonesia's power generation mix, while oil is still dominating the country's energy mix.

President Yudhoyono pledge in Pittsburgh (2009) that Indonesia would voluntarily reduce the country's greenhouse gas emissions by 26 percent from business-as-usual levels by 2020 , which can be increased to 41 percent when added with foreign aid. The President's pledge became the base for the stipulation of the National Action Plan for Greenhouse Gas

\footnotetext{
${ }^{18}$ Also recommended by the Minister of Research and Technology/Head of the National Research and Innovation Agency
} 
Emission Reduction (Presidential Regulation Number 61 of 2011) and several regulations, and institutions established following the pledge.

Indonesia's renewable energy performance is lower than it is expected. The achievement of the share of renewable energy in Indonesia's energy mix is always lower than the target. In fact, there are fundamental obstacles that hinder the achievement of renewable energy development targets, and these are important to be resolved first.

As suggested by literature, to be able to achieve the targets of renewable energy development, several requirements must be met. Among others are laws and regulations in favor of developing renewable energy, economic and investment environment that encourages the development of renewable energy, innovations and renewable energy technology, public awareness, and institutions in charge of developing renewable energy.

Fundamentally, we need to understand that economic growth, demand for energy and emissions released by Indonesia in the last few decades have always increased by all the three. This is a trend that should not be sustained. On the other hand, Indonesia should expand the application of energy conservation principles in various activities that consume energy, in addition to continuously increasing the use of renewable energy relative to other types of energy.

To get closer to achieving the Paris Agreement targets, Indonesia needs to develop an economic-energy-environment model like Germany's, where a growing economy is accompanied by lower energy use and emissions. It needs to prioritize reforming the fundamentals in renewable energy development rather than directly setting quantitative targets.

While waiting for the issuance of new laws and regulations linking the Paris Agreement with Indonesia's renewable energy development goals, we recommend doing the following basic things:

- Ensure that the Law on New \& Renewable Energy will soon be promulgated.

- Establish regulations regarding renewable energy pricing.

- Develop and implement a carbon pricing system, which may be preceded by removing subsidies for fossil fuels, implementing a carbon tax, developing a carbon trading system, and so on.

- Establish organizational units regarding climate change in government offices, especially those closely related to climate change issues such as the Ministry of Energy, Industry, Transportation, Public Works, Agriculture, etc.

- Develop technology and industries related to increasing the contribution of renewable energy, especially those sourced from within the country.

- Improve data quality dan grid intrconnection

- Implement energy conservation in various applications.

- Encourage the development of Renewable Energy Based Industrial Development (REBID) and Renewable Energy Based Economic Development (REBED).

\section{References}

Government of Indonesia, 2004. National Medium Term Development Plan 2004-2009.

Government of Indonesia, 2015. National Medium Term Development Plan 2015-2019. 
Government of Indonesia, 2017. President Regulation number 22 of 2017 concerning National Energy General Plan.

Government of Indonesia, 2020. President Regulation number 18 of 2020 concerning the 20202024 National Medium-Term Development Plan.

IRENA, 2020. Renewable energy statistics.

Martin, G., 2009. Tailoring renewable energy portfolio standards: achieving desperate economic and environmental goals through RPS design. Riga: VDM Verlag.

Mendonca, M., 2007. Feed-in tariff: Accelerating the development of renewable energy. London: World Future Council.

Murniningtyas, E., 2013. Indonesia National Action Plan on Climate Change Adaptation (RANAPI). Paper presented at COP 19 - UNFCCC Warsaw, 18 November 2013.

Nugroho, H., 2015. Redefining Indonesia's energy security: Efforts to adopt cleaner, more sustainable energy strategies. In National Bureau of Asian Research: Indonesia, a regional leader in transition, 46-59.

Nugroho, H., 2018a. Thought on Indonesian energy issues \& policies. Bogor: IPB Press.

Nugroho, H., 2018b. Steep Road: Energy transition and the role of development planning in Indonesia. Prisma Journal of Social Economy Thoughts, 37 (1), 3-19.

Nugroho, H., 2019. Indonesia's energy development: Evaluation of the 2015-2019 Medium-Term development Plan and outlook for that of 2020-2024. The Indonesian Journal of Development Planning, 3(3), 266-272.

Nugroho, H. \& Rustandi, D., 2020. An analysis of the possibility to achieve the specified Indonesian renewable energy development target: Status and proposal for the 2020-2024 National Medium-Term Development Plan. Hawaii: The IAFOR International Conference on the Sustainability, Energy \& the Environment.

Nugroho, H. \& Muhyidin, 2021. Decline and increase, progress but not enough: Energy sector development performance amid the 2020 Covid-19 pandemic. Bappenas Working Papers, $4(1), 1-12$.

Nugroho, H., 2021. Which Pathways Should Indonesia Follow to Achieve Its Energy Development Goals into the Future? The Journal of Indonesia Sustainable Development Planning, 2(1), 106-110.

Purwanto, W. \& Pratama, Y., 2017. Analysis of Indonesia's renewable energy policy: Status, barriers, and opportunities. Depok: University of Indonesia Press.

Republic of Indonesia, 2007. Law number 30 of 2007 on Energy.

Republic of Indonesia, 2014. Government regulation in lieu of law number 79 of 2014 on National Energy Policy.

Sinaga, L., 2020. Assessing the Commitment of Indonesian Government Towards Climate Change Policy: The Yudhoyono Presidency 2004-2014. Jurnal Politica, 11 (2), 163-181.

Sovacool, B. 2012. Policy lessons from ten renewable energy access programs in developing Asia. The Journal of energy and development, 37(1), 1-44.

United Nations - ESCAP, 2020. Energy Transition Pathways for the 2030 Agenda SDG7: Roadmap for Indonesia. 